\title{
A praenatalis és postnatalis mikrobiom jelentősége és hatásai a korai egyedfejlődés időszakában és az intervenciós kezelés lehetőségei
}

\author{
Fülöp Vilmos dr. ${ }^{1,2}$ - Demeter János dr. ${ }^{1}$ - Cseh Áron dr. ${ }^{3}$ \\ ${ }^{1}$ Magyar Honvédség Egészségügyi Központ, Szülészet-nőgyógyászati Osztály, \\ Semmelweis Egyetem Gyakorló Kórház, Budapest \\ ${ }^{2}$ Miskolci Egyetem, Egészségügyi Kar, Miskolc \\ ${ }^{3}$ Semmelweis Egyetem, Általános Orvostudományi Kar, I. Gyermekgyógyászati Klinika, Budapest
}

\begin{abstract}
A humán mikrobiom az emberi szervezetben és az emberi testfelszínen élő mikrobaközösségek összessége, amelyek többsége a gyomor-bél rendszerben él. Ezek a mikrobaközösségek számos és sokféle baktériumot tartalmaznak, gombákat, vírusokat, archeákat és protozoonokat. Ez a mikrobiális közösség, vagy mikrobiota, a gazdaszervezetben nagyrészt egymással kölcsönösségi viszonyban tenyészik, és gondoskodik a bélben a tápanyagok anyagcseréjéről, kalibrálja az anyagcsere-múköóést, tanítja az immunrendszert, fenntartja a közösség integritását, és véd a kórokozók ellen. A majdan megszületendő magzat a megfelelő tápanyagellátását az anyai véráramból kapja, és így az anyai szervezetben a mikrobiota indukálta baktériumkomponensek vagy metabolitok hatékonyan átvihetők a magzatba. Az anyai mikrobiális közösségek - ideértve a praenatalis bélrendszeri, hüvelyi, száj- és bőrmikrobiomot - a terhesség alatt valójában kifejezett változásokon mennek keresztül, amelyek befolyásolhatják az egészség megőrzését, és hozzájárulhatnak a közismert betegségek kialakulásához. A magzat nem steril, és immunológiai szempontból sem naiv, hanem az anya révén környezeti ingerek hatásaitól befolyásolva kölcsönhatásba lép az anyai immunrendszerrel. Számos anyai tényező - beleértve a hormonokat, a citokineket és a mikrobiomot - módosíthatja az intrauterin környezetet, ezáltal befolyásolva a magzati immunrendszer fejlődését. A fokozott stresszben éló anyák csecsemőinél nagyobb az allergia és a gyomor-bél rendszeri rendellenességek aránya. A várandós étrendje is befolyásolja a magzati mikrobiomot a méh közvetítésével. A bélflóránk, vagyis a mikrobiom, a belünkben éló mikrobák összessége és szimbiózisa, amelynek kényes egyensúlya már csecsemőkorban kialakul, és döntően meghatározza az intestinalis barrier és a bélasszociált immunrendszer múködését. A probiotikumok szaporodásához szükséges prebiotikummal is befolyásolható a bélflóra. A pre- és a probiotikum kombinációja a szimbiotikum. Az anyatej a patogénekkel szemben protektív hatású, részben azáltal, hogy emeli a Bifidobacterium-számot az újszülött bélflórájában. A dysbiosis a kommenzális, egészséges bélflóra megváltozása. Ennek szerepét feltételezik funkcionális gastrointestinalis kórképekben, egyre több pszichiátriai és neurológiai kórképben is, mint az autizmus-spektrumzavar.
\end{abstract}

Orv Hetil. 2021; 162(19): 731-740.

Kulcsszavak: anyai mikrobiális közösségek, intrauterin környezet, magzati immunrendszer, anyatej-mikrobiom

\section{Significance and effects of prenatal and postnatal microbiome in the period of early individual development and options for interventional treatment}

The human microbiome is the totality of microbe communities living in the human body and on the human body surface, most of which live in the gastrointestinal tract. These microbe communities contain many and varied bacteria, fungi, viruses, archaea and protozoa. This microbial community or microbiota in the host is largely reciprocal and takes care of nutrient metabolism in the gut, calibrates metabolism, teaches the immune system, maintains community integrity, and protects against pathogens. The fetus to be born is adequately supplied with nutrients from the maternal bloodstream, and thus microbial-induced bacterial components or metabolites can be efficiently transferred to the fetus in the maternal body. Maternal microbial communities, including prenatal intestinal, vaginal, oral, and dermal microbiomes, actually undergo pronounced changes during pregnancy that can affect health maintenance and contribute to the development of well-known diseases. The fetus is not sterile or immunologically naïve, but 
interacts with the maternal immune system through the effects of environmental stimuli through the mother. Many maternal factors, including hormones, cytokines, and the microbiome, can modify the intrauterine environment, thereby affecting the development of the fetal immune system. Infants of mothers under increased stress have higher rates of allergies and gastrointestinal disorders. The diet of the gravida also affects the fetal microbiome through the uterus. Our intestinal flora, or microbiome, is the totality and symbiosis of the microbes living in them, the delicate balance of which is established in infancy and decisively determines the functioning of the intestinal barrier and the intestinal associated immune system. The prebiotic required for the proliferation of probiotics can also affect the intestinal flora. The combination of pre- and probiotic is symbiotic. Breast milk has a protective effect against pathogens, in part by raising the number of Bifidobacteria in the intestinal flora of the newborn. Dysbiosis is a change in the commensal, healthy gut flora. Its role is hypothesized in functional gastrointestinal disorders, as well as in more and more psychiatric and neurological disorders such as the autism spectrum disorder.

Keywords: maternal microbial communities, intrauterine environment, fetal immune system, breast milk microbiome

Fülöp V, Demeter J, Cseh Á. [Significance and effects of prenatal and postnatal microbiome in the period of early individual development and options for interventional treatments]. Orv Hetil. 2021; 162(19): 731-740.

(Beérkezett: 2020. október 12.; elfogadva: 2020. november 24.)

\section{Rövidítések}

16S rDNS = 16S riboszomális DNS -t kódoló gén (a baktériumok nemzetség- és fajszintű meghatározása során többek között a $16 S$ rDNS vizsgálata alkalmazható); DNS = dezoxiribonukleinsav; $\mathrm{IBD}=($ inflammatory bowel disease $)$ gyulladásos bélbetegség; IgA = immunglobulin-A; IL = interleukin; MAIT $=$ (mucosa-associated invariant $\mathrm{T}$ cells $)$ nyálkahártyaasszociált invariáns T-sejtek; MALT $=$ (mucosa-associated lymphoid tissue) nyálkahártyához társult nyirokszövet; $\mathrm{NF}_{\kappa} \mathrm{B}$ = nukleárisfaktor-kappa-B (az aktivált B-sejtek kappa-könnyúláncát erősítő nukleáris [sejtmag-] faktor, egy olyan fehérjekomplex, amely szabályozza a DNS transzkripcióját, a citokintermelést és a sejtek túlélését); SCFA = (short chain fatty acid) rövid láncú zsírsav

A humán mikrobiom az emberi szervezetben és az emberi testfelszínen élő mikrobaközösségek összessége, amelyek többsége a gyomor-bél rendszerben él. Ezek a mikrobaközösségek számos és sokféle baktériumot tartalmaznak, gombákat, vírusokat, archeákat (ősbaktériumok: Crenarchaeota és Euryarchaeota törzsek) és protozoonokat. Ez a mikrobiális közösség, vagy mikrobiota, a gazdaszervezetben nagyrészt egymással kölcsönösségi viszonyban tenyészik, és gondoskodik a bélben a tápanyagok anyagcseréjéról, kalibrálja az anyagcsere-múködést, tanítja az immunrendszert, fenntartja a közösség integritását, és véd a kórokozók ellen [1]. Egyre több bizonyíték utal arra, hogy ennek a közösségnek a felbomlása (dysbiosis) számos, nem fertőző betegség, például asthma, allergia, elhízás és autoimmun betegségek alapját képezheti [2].

Csíramentes egereket használó elegáns modelleken mutatták ki a mikrobiota fontos szerepét az immun- és más szervrendszerek fejlődésében [3]. Mikrobiota hiányában a bél IgA-termelése és T-helper-sejt-differenciálódása erősen csökkent, a másodlagos és harmadlagos lymphoid szervek (nyirokcsomók, Peyer-plakkok és az izolált nyiroktüsző́k) fejletlenek, és a veleszületett immunrendszer hiporeaktív.

A majdan megszületendő magzat a megfelelő tápanyagellátását az anyai véráramból kapja, és így az anyai szervezetben a mikrobiota indukálta baktériumkomponensek vagy metabolitok hatékonyan átvihetók a magzatba.

\section{Az anyai mikrobiom befolyása a magzatra}

Az anyai mikrobiális közösségek - ideértve a praenatalis bélrendszeri, hüvelyi, száj- és bőrmikrobiomot - a terhesség alatt valójában kifejezett változásokon mennek keresztül, amelyek befolyásolhatják az egészség megőrzését, és hozzájárulhatnak a közismert betegségek kialakulásához [4]. A csecsemő bélrendszerének mikrobiális dysbiosisát eddig az asthma, az allergiás betegségek és az elhízás kialakulásával társították $[5,6]$. Így figyelembe véve azokat a megállapításokat, hogy a magzat nem steril környezetben fejlódik, és hogy a mikrobiális kolonizáció a méhben kezdődik, az első kolonizációt befolyásoló tényezők hatással lehetnek az újszülött jövőbeli egészségére.

Ma már ismert fontos tény, hogy a magzat nem steril, és immunológiai szempontból sem naiv, amint azt korábban feltételezték, hanem az anya révén környezeti ingerek hatásaitól befolyásolva kölcsönhatásba lép az anyai immunrendszerrel [7]. Látszólag normális terhességből származó köldökzsinórvérben, magzatvízben, magzatburokban és méhlepényben sokféle mikrobát detektáltak, gyulladásra vagy patológiai eltérésekre utaló jelek nélkül. Fontos szempont, hogy a meconium mikrobiotáját (az első székletmintát, amelyet a magzati gastrointestinalis rendszer tartalmának helyettesítőjeként lehet használni) az alacsony biodiverzitás és az egyének közöt- 
ti nagy variabilitás jellemzi [8]. Bäckbed és mtsai megállapították, hogy a csecsemők mikrobiotájához viszonyítva a meconium-mikrobiota gazdagabb volt Escherichia és Enterococcus nemzetségekben, a Bacteroides és a Bifidobacterium pedig kisebb mennyiségben volt jelen [9]. Összefoglalva: az irodalomban egyetértés van abban, hogy a meconium-mikrobiomnak egyedi összetétele van, és benne a proteobaktériumok és a Firmicutes törzs baktériumai dominálnak. A tanulmányok között egyetértés van abban is, hogy a meconiummintákban gyakran megtalálhatók a felnőttkori gastrointestinalis traktus baktériumai. Mindamellett arról is beszámoltak, hogy a meconium mikrobiomja hasonló ahhoz, amely a magzatvízben, a méhlepényben és a colostrumban megtalálható.

Számos anyai tényező - beleértve a hormonokat (például progeszteron), citokineket és a mikrobiomot - módosíthatja az intrauterin környezetet, ezáltal befolyásolva a magzati immunrendszer fejlődését [10]. A toll-szerü receptorok olyan receptorosztályt képviselnek, amely a természetes immunitásban részt vevő különböző sejtek (macrophagok, hízósejtek és dendritikus sejtek) felületén jelennek meg. Mivel a toll-szerü receptor különféle típusai különböző baktériumokat képesek felismerni, amelyek potenciális gyulladásos válasz kialakulását idézik elő, úgy vélik, hogy az intrauterin baktériumok a tollszerú receptorokon keresztül befolyásolhatják a magzati immunrendszer fejlődését [11]. A magzati immunrendszer fejlődését befolyásoló baktériumhatás további lehetséges mechanizmusát olyan SCFA-k előállítása képviselheti, amelyek indukálják a T-sejtek aktiválását, és modulálják az IL10-termelést [12].

Kimutatták, hogy a normál súlygyarapodású anyáktól született újszülöttekkel összehasonlítva, kóros terhességi súlygyarapodás esetén az újszülöttekben alacsonyabb a Bacteroides és a Prevotella nemzetség aránya [12]. A terhességi és a praegestatiós 2. típusú cukorbetegségnek és a meconium-mikrobiom összetételének összefüggését vizsgálva érdekes módon azt találták, hogy anyai cukorbetegség fennállásakor a Bacteroides és Parabacteroides fajokban, valamint a Lachnospiraceae család képviselőiben gazdagabb volt a csecsemők meconiuma, és hogy ezek a változások nagyobb arányúak voltak praegestatiós cukorbetegség esetén [12]. Gosalbes és mtsai igazolták az anyai atopiás betegségeknek a meconium-mikrobiomra gyakorolt hatását [13]. Megállapították, hogy az anya ekcémája képes módosítani a meconiumbaktériumok összetételét, mivel kevesebb baktériumvariabilitással és -mennyiséggel, valamint az Enterobacteriaceae család megnövekedett mennyiségével jár együtt. Ugyanakkor úgy tünik, hogy az anyai asthma vagy orrgyulladás nem vált ki mikrobiális változásokat [13]. Mshvildadze és mtsai pedig kimutatták, hogy a szülésük alatt antibiotikumot használó anyák csecsemőinek meconiumában alacsonyabb volt a baktériumok variabilitása [14].

A jelenlegi epidemiológiai adatok szerint a császármetszéssel született csecsemők körében magasabb az atopiás betegség aránya, mint a per vias naturales született társaiknál [15]. A csecsemőknek csak körülbelül az egynegyedébe jutnak születésükkor anyai hüvelyi Lactobacillusok, a betelepedett Lactobacillusok azonban nem maradnak sokáig a bélrendszerükben, mivel ezeket gyorsan felváltják az anyatejből származó Lactobacillusok [16]. Egyes közlemények szignifikáns különbségről számoltak be a hüvelyi úton és a császármetszéssel szült csecsemők meconiumának mikrobiotájában. Dominguez-Bello és mtsai szerint a császármetszéssel és a hüvelyi úton született csecsemők mikrobiotája között az első életévben különbség mutatkozik, mivel a hüvelyi úton szült csecsemőkre a Bifidobacterium spp. felszaporodása és az Enterococcus és Klebsiella spp. csökkenése jellemző. A császármetszéssel világra jött csecsemők Bifidobacteriummal történő kolonizációja késik. Az extrauterin élet első hetének mikrobiota-összetétele összefüggésben áll a légúti fertőzések számával. Az ezeket kiváltó taxonok nagyobb számban fordulnak elő császármetszéssel született gyermekeknél, ami a szülés módja és a fertőző betegségekre való hajlam közötti kapcsolatra utal [17]. Del Chierico és mtsai azonban olyan alapmikrobiotát azonosítottak, amelynek jelenléte független volt a szülés módjától [18]. Hasonlóképpen, a placentalis mikrobiota értékelésekor Aagaard és mtsainem észleltek különbségeket a per vias naturales vagy a császármetszés útján megszületett (eltávolított) méhlepények baktérium-összetételében [19].

A szülés előtt az anyának adagolt antibiotikum hüvelyi mikrobiota-dysbiosist idéz elő, amelyre az antibiotikumrezisztens polimikrobiális környezet (ideértve a Citrobacter spp.-t, az Enterobacter spp.-t és az Escherichia colit) kialakulását elősegítő Lactobacillus spp. számának csökkenése jellemző [20]. Ezek a mikrobák ezután vertikálisan aszcendálnak az intrauterin környezetbe, még a kezelés befejezése után is befolyásolva a korai kolonizációs eseményeket és az újszülött bélrendszerének mikrobiotáját. A perinatalis antibiotikumexpozíciót az utódok számos súlyos morbiditásával, köztük az asthmával és a nekrotizáló enterocolitisszel társították. A szülés előtti antibiotikumprofilaxis feltételezhetően megsemmisíti a kommenzális (velünk élő) baktériumokat, és elősegíti a csecsemők antibiotikumrezisztens baktériumokkal történő kolonizálását. Szignifikáns és tartós különbséget figyeltek meg a szülés elötti antibiotikumprofilaxis hatásának kitett anyáktól született és az olyan anyáktól született csecsemők bélmikrobiotája között, akik nem kaptak szülés előtti antibiotikumprofilaxist. Az anyai antibiotikumexpozíciót az újszülött bélrendszerében a baktériumok diverzitásának csökkenésével és a Lactobacillusok és Bifidobacteriumok alacsonyabb mennyiségével társították.

Megállapították, hogy a bél mikrobiotája drámai módon eltolódhat a praeeclampsiában szenvedő betegeknél. A bél dysbiosisa praeeclampticus elváltozásokat okozhat. Ennek egyik mechanizmusa lehet a bél-gát károsodása és a kórokozó baktériumok transzlokációja a bélből a placentába, ahol kóros immunválaszokat okoznak. A prae- 
eclampsiás humán és egérplacentában a Fusobacterium magasabb szintjét azonosították, ami kórosan befolyásolja a magzati mikrobiom kolonizációját is. Ennek élethosszig tartó kedvezőtlen hatásai lehetnek egyes súlyos kórállapotok (stroke, infarktus stb.) kialakulásának kockázatára. Feltehetőleg a Fusobacterium hatása alatt álló „bél-placenta” tengely döntő szerepet játszhat a praeeclampsia etiológiájának megértésében [21].

Az autizmus egérmodelljében kimutatták, hogy a praenatalis mikrobiota-transzplantáció képes modulálni a várandós immunrendszerét és átjuttatni az idegfejlődési rendellenességek iránti érzékenységet az utódokba [10].

A praenatalis stressz és a várandósok egészsége szintén befolyásolhatja a mikrobiomjukat. Az egészséges csecsemők vizsgálata során kiderült, hogy az anyai praenatalis stressz a proteobaktériumok kórokozó tagjainak nagyobb mennyiségével és két, általában a jó egészségi állapottal kapcsolatba hozható baktérium (Bifidobacterium és Lactobacillus) kisebb gyakoriságával jár együtt [22]. A stressznek különösen késői terhességi korban kitett várandósok utódainál a 2. post partum napon szignifikánsan kevesebb Lactobacillus-és Bifidobacterium-menynyiséget mértek a kontrollhoz képest [22]. A fokozott stresszben élő anyák csecsemóinél nagyobb az allergia és a gyomor-bél rendszeri rendellenességek aránya is, ami arra utal, hogy a stressz által megváltozott anyai mikrobiomnak káros hatása lehet az egészségre.

Az anyatej mikrobiomjában megtalálhatók a bélcsatornában leggyakrabban jelen levő anaerob baktériumok, mint például a Bifidobacterium és az Enterococcus. $\mathrm{Az}$ anyatej a patogénekkel szemben protektív hatású, részben azáltal, hogy emeli a Bifidobacterium-számot az újszülött bélflórájában. Ismert, hogy az anyatejes táplálás számos betegség, így az IBD gyakoriságát is csökkenti. A dysbiosis jellemzője IBD-ben a csökkent számú Firmicutes, Bacteroides, valamint a nagyobb számú, egyéb Proteobacteria törzsbe tartozó baktériumok, így az E. coli is. Ezzel egyrészt csökken a biodiverzitás (például Firmicutes-tagok), de ugyanígy a SCFA-kat termelő baktériumok szintje is (Clostridium cluster IV, XIVa, XVII és a Faecalibacterium prausnitzii), amelyek gyulladáscsökkentő, oxidatív stresszt gátló hatásúak lennének. Ugyanakkor nő a mukolitikus (Ruminococcusgnavas és torques), a szulfátredukáló (Desulfovibrio) és az egyéb patogén baktériumok (invazív E. coli) mennyisége [23].

\section{A magzati mikrobiom forrásai: az anyai bélcsatorna, szájüreg és hüvely}

A bélepithelialis gát általában megakadályozza a baktériumok belépését a véráramba; a dendritikus sejtek azonban baktériumokat vesznek fel a bél lumenéből. Ezek a baktériumokkal „felpakolt” dendritikus sejtek irányított vándorlással a bél nyirokedényein keresztül a mesenterialis nyirokcsomóba kerülhetnek [24]. Leírták, hogy a dendritikus sejtek itt néhány napig elkülönítik (szekvesztrálják) az élő kommenzális baktériumokat [6]. Mi- után a baktériumok hozzákapcsolódtak a dendritikus sejtekhez, átjuthatnak a nyirokrendszerbe, és a szervezetben más helyekre is terjedhetnek a MALT-rendszerben keringő lymphocyták révén [25].

A terhesség során általánosan jelen lehetnek olyan folyamatok, amelyek elősegítik a baktériumok transzlokációját a méhlepénybe, a méhlepényen történő átjutásukat és kontaktusukat a fejlődő magzattal. Terhesség alatt a bél-gát rendszer áteresztőképessége megnövekedik, és a szájüregi vérzések is gyakrabban fordulnak elő. Ezek a változások a terhesség hormonális és cardiovascularis változásaival vannak összefüggésben. Ezért a Prevotella, a Streptococcus és a Veillonella a szájüregből és/vagy a bél lumenéból bejuthat a véráramba, és kolonizálhatja a méhlepényt [26].

A baktériumoknak az anyából a magzatba irányuló átjutása fiziológiai okokból, például a magzati bél immunfejlődésének elősegítésére alakulhatott ki, ahol befolyásolhatják a magzati immunrendszer „oktatását” és az immunválaszt. Különböző hipotéziseket javasoltak a méhlepény kolonizációjának mechanizmusára: vertikális irányú transzlokáció a hüvely felől, vagy hematogén terjedés az anyai bélcsatornából és a szájüregből (1.ábra).

Vizsgálatok felfedték, hogy a szájon át bevett mikrobiális DNS átjutott a magzatba, és hogy az egerekben a per os elfogyasztott élő baktériumok a magzatvízen keresztül el tudnak jutni a magzati gastrointestinalis traktushoz.

Az anyai bélbaktériumokban és az újszülött-meconiumban jelen levő azonos törzsek azt jelzik, hogy a magzat az anyai bélrendszerből származó mikrobák behatása alatt áll. Gosalbes és mtsai közölték, hogy a meconium mikrobiotáját a várandós étrendje és még a dohányzása is befolyásolhatja [13]. Néhány behatás a terhesség alatt kórosan megváltoztatja az anyai mikrobiomot, és fokozhatja a bél permeabilitását és a bélfalon keresztül történő transzlokációt, megkönnyítve a várandós baktériumainak bejutását a méh környezetébe [27]. Számos vizsgálat alapján feltételezhető, hogy a bél mikrobiom-kolonizációja praenatalisan kezdődik a baktériumoknak a placentán keresztül történő átjutásával vagy a magzatvíz lenyelésével. A magzati bél kolonizációja a „megfelelő” baktériumokkal normális folyamat lehet, míg in utero a „rossz” baktériumok akvizíciója a negatív anyai behatások miatt befolyásolhatja a gyermekek jövőbeli betegségkockázatát. Így a mikrobák anyaméhbe történő átvitele a csecsemő számára kedvező és káros következménnyel is járhat. A normál étrendü kontrollcsoporthoz képest a magas zsírtartalmú nyugati étrenden tartott vemhes egerek kórosan megváltoztatták bélmikrobiomjukat, és utódaikban szignifikánsan alacsonyabb volt a teljes baktériummennyiség, nagyobb volt a Firmicutes és a Bacteroides aránya, és kóros irányba változott az immunfejlődésük [27].

A hüvelyi mikrobiom - méhközeli anatómiai helyzete miatt - a magzati mikrobiom betelepedésének és kialakulásának az egyik lehetséges forrása. A hüvelyi aszcendáló terjedésen túlmenően úgy gondolják, hogy az en- 


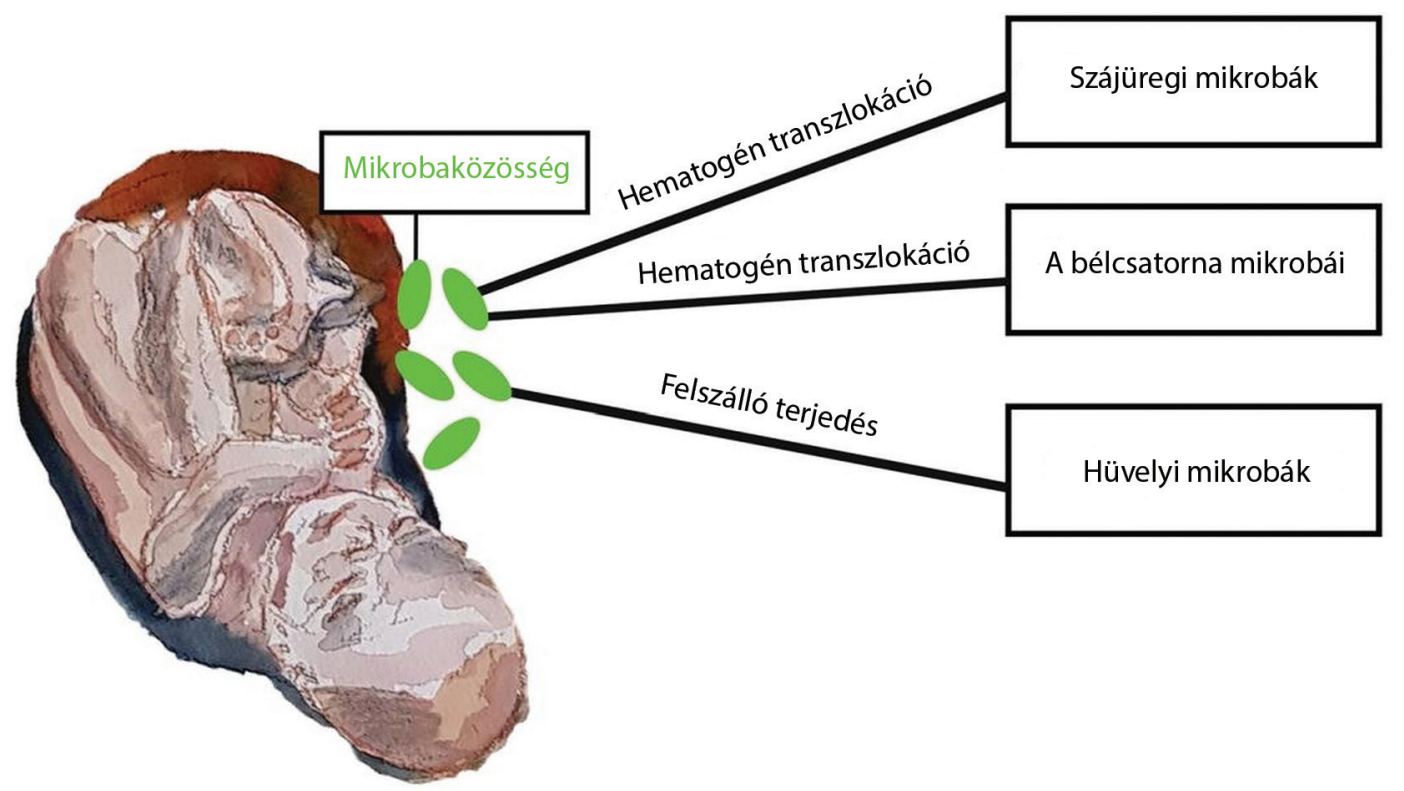

1. ábra

A placenta mikrobiomjának kolonizációja. A mikrobák felfelé terjednek a hüvelybőll, továbbá a bélcsatornából és a szájüregből (miután internalizálódtak a dendritikus sejtekbe) hematogén terjedés révén transzlokálódnak a méhlepénybe

dometriumban olyan baktériumok találhatók, amelyek a terhesség beágyazódási szakaszában épülnek be a méhlepénybe, ami arra utal, hogy a szülés előtt a magzat a hüvelyi vagy uterinalis forrásból származó baktériumok hatásának lehet kitéve [27]. Bebizonyosodott, hogy a terhesség alatt a mikrobák a hüvelyből feljuthatnak és betörhetnek az amnionưrbe. Az aszcendáló hüvelyi mikrobákat összefüggésbe hozták a méhen belüli gyulladással és a koraszülés patogenezisével. A Mollicutes osztályba tartozó baktériumok (különösen az Ureaplasma parvum és az Ureaplasma urealyticum) tipikus hüvelyi kolonizátorok, és a leggyakrabban izolált mikrobák a koraszülésekből származó magzatvízben [6]. Ezekről a baktériumokról kimutatták, hogy erôs intrauterin gyulladásos reakciót váltanak ki, ami koraszüléshez vezet [28]. A hüvelyre jellemző, nem patogén baktériumok - mint például a Lactobacillus spp. - is jelen vannak az egészséges, teljesen kihordott terhességek amnionúrében.

A terminusban született csecsemők független kohorszain végzett további tanulmányok is megállapították, hogy a hüvelyen keresztül született (per vias naturales) újszülöttek meconium-mikrobiotájában tejsav- vagy bélbaktériumok dominálnak [13]. A hüvelyi szülés során létrejött anyai eredetű kolonizáció elengedhetetlen e baktériumfajok korai életben történő akvirálásához.

Annak ellenére, hogy térben elkülönül a méhtest üregétől, úgy vélik, hogy az anyai szájüreg is szolgálhat a magzati mikrobiális kolonizáció forrásaként. A szájüregből származó hematogén elterjedés szélesebb körü figyelmet kapott, miután a parodontalis betegség és a koraszülés kapcsolata köztudott. A placentaris mikrobiális közösségeket jellemző legnagyobb metagenomikus tanulmány kimutatta, hogy a placentaris mikrobiom kü- lönbözik a szervezet többi helyének mikrobiomjától, bár némi hasonlóságot mutat a nem terhes nők oralis mikrobiomjával [26]. Aagaard és mtsai adatai szerint a placentalis mikrobiom bakteriális összetétele jobban hasonlított a szájüreg mikrobiomjához, mint a szervezet bármely más helyén előforduló kolóniákhoz (beleértve a hüvelyt és a bélrendszert) [19]. A korábbi vizsgálatok olyan patogén oralis fajokat fedeztek fel a periodontalis betegségben szenvedő nők méhlepényében és magzatvizében, mint például a Fusobacterium nucleatum és a Porphyromonas gingivalis, ami arra utal, hogy lehetséges az opportunista baktériumok migrációja a szájüregból a méhbe. A praeeclampsiás nők 13\%-a hordoz olyan baktériumokat, amelyekről ismert, hogy gastrointestinalis fertőzéssel és periodontitisszel járnak. Ez arra utal, hogy oralis-placentaris mikrobiom-kapcsolat áll fenn. A placenta vagy a magzatburok szöveteinek bakteriális fertőzését a koraszülés kockázatának tekintik, azzal a megfigyeléssel összhangban, hogy a koraszülések alkalmával a méhlepényben a patogén baktériumok nagyobb mennyiségben fordulnak elő [27]. Úgy tûnik, hogy a terhességi betegségekkel társuló periodontalis vagy egyéb eredetű fertőzések esetén a vérben jelen levő baktériumok a lepénybe irányuló hematogén bakteriális transzlokáció forrásai lehetnek.

A kommenzális baktériumok jelenléte a magzatban, a magzatburokban és a magzatvízben tehát már jól megalapozott [6].

Érdekes módon azok a baktériumok, amelyek a placentaris mikrobiomot alkotják, a többi mikrobiomhoz viszonyítva eltérő funkcionális kapacitással rendelkezhetnek. Míg a szájüregi és a bélben található mikrobák a szénhidrát- és aminosav-anyagcserében, valamint a vita- 
minok bioszintézisében játszanak szerepet, a placentaris mikrobiomok olyan génekben gazdagok, amelyek a triptofán-, a zsírsavanyagcserét és a benzoátlebomlást szabályozzák. A placenta triptofán-anyagcseréje fontos a magzati idegfejlődésben, és a placentaris triptofánmetabolizmus zavarait a magzat kórosan megváltozott idegfejlődési folyamataival társítják. A méhlepényben a triptofánt bontó anyagcsere kapcsolatban van a fetomaternalis immuntolerancia kialakulásával és fenntartásával, a placenta keringésével és növekedésével, valamint az antimikrobiális aktivitás modulálásával azáltal, hogy gátolja a felszálló fertőzéseket a hüvelyből. Ez a placentaris mikrobákkal túlreprezentált reakció-útvonal a természetes placentaris kolonizátorok szelekcióját jelezheti, ami megakadályozza az idegen mikroorganizmusok kolonizációját [26].

\section{A magzati bél immunprogramozása}

Még nem teljesen ismert mechanizmusok révén, az anyai keringő immunsejtek (dendritikus sejtek) és a bélhámsejtek paracelluláris tere közötti kapcsolat megnyitja a junctiós komplexeket (sejtkapcsoló szerkezetek), és lehetővé teszi a dendritikus sejtek számára, hogy az anyai bél lumenéből közvetlenül felvegyék és internalizálják a mikrobiotát. Az internalizált bélbaktériumok a keringésen keresztül különböző szervrendszerekbe, így a méhlepénybe juthatnak. Az anyai bélpermeabilitás változásai a terhesség és a szülés során kulcsfontosságú szerepet játszhatnak a baktériumok transzlokációjában [29].

A bélben található baktériumok megtalálhatók az anyatejben is, amiben ugyanez a transzlokációs mechanizmus játszhat szerepet. Ezen elmélet további alátámasztására kimutatták, hogy egerekben a gastrointestinalis traktusból származó mikrobiális transzlokáció fokozódik a terhesség ideje alatt. Perez és mtsai megállapították, hogy a vemhes egerek 60\%-kal nagyobb valószínüséggel hordanak baktériumokat mesenterialis nyirokcsomóikban, mint a nem terhes egerek, ami valószínúleg a dendritikus sejtek által irányított vándorlásának (trafficking) növekedését jelzi, ami biztosítja a magzati üregekben az anyai mikrobiális expozíciót [25].

A magzati mikrobiota valószínúleg fontos szerepet játszik az immunológiai fejlődésben. A bélmikrobák a baktériumokból származó metabolitok, például SCFA-k hatása révén modulálhatják az immunrendszer fejlődését és múködését. Egyre több bizonyíték utal arra, hogy a nem patogén bélbaktériumok sokkal korábban kezdhetik meg az immunprogramozást, mint ahogyan azt korábban elképzeltük [6].

A humán bélrendszerben az oldhatatlan táplálékrostok fermentációja és lebontása a bél mikrobiota-rendszerén alapszik, miáltal SCFA-k jönnek létre. Ekkor a mikrobiális eredetű SCFA-k kölcsönhatásba léphetnek az immunrendszerrel: 1) elősegítik a bél hámsejtjeinek nyáktermelését; 2) gerjesztik a B-sejtek IgA-kiválasztását; 3) gyulladásgátló hatásuk van, ami különösen az $\mathrm{NF}$ kB gátlásán keresztül érvényesül; 4) elősegítik a regu- látor T-sejtek kialakulását a bélben, ezáltal támogatják az immunológiai toleranciát; 5) az inflammaszómaaktiválástól és az IL18-termeléstől függő folyamat révén fokozzák az epithelialis réteg integritását; és 6) előmozdítják a szövetkijavítási és a sebgyógyulási folyamatokat [30].

Míg a csíramentes kontrollegerek utódaival összehasonlítva az adaptív immunsejtek, mint például a B- és a T-helper-sejtek alcsoportjai változatlanok voltak a terhesség alatt kolonizált egerek utódaiban, szignifikáns változásokat észleltek a veleszületett immunrendszer összetevőiben [31]. Különösen a vékony- és a vastagbélben a vékonybél 3-as típusú NKp46+ természetes lymphoid sejtek (ILC3) és az intestinalis F4/80+CD11 C $^{+}$ mononukleáris sejtek (ILC3) relatív és abszolút száma növekedett meg [32].

Az anyából eredő kolonizáció átprogramozza az utódok béltranszkripciós profilját, ami az epithelialis antibakteriális peptideket és a mikrobiális molekulák metabolizmusát kódoló gének fokozott kifejeződését eredményezi. Ezen hatások némelyike az anyai antitestektől függ, amelyek potenciálisan megtartják a mikrobiális molekulákat, majd azokat az utódokba továbbítják a terhesség alatt és a szoptatás során. A terhességük alatt átmenetileg kolonizált állatok utódai jobban elkerülték a mikrobiális molekulákra adott gyulladásos válaszokat és a bélmikrobiom bélfalon keresztüli átjutását [31].

Érdekes kérdés, hogy hogyan tudnak az anyai antitestek hozzájárulni az utódok ezen immunváltozásaihoz. Két lehetőség van: 1) a terhesség alatt az anyai nyálkahártya feltöltődése jelentősen növeli a szérumban az immunglobulinok koncentrációját, és az utódokat ezáltal elérő magasabb antitest-koncentráció közvetlen változásokat válthat ki az immunrendszerükben, vagy 2) a specifikus ellenanyagok a baktériumtermékekhez kötődhetnek, így az anyai szervezetben tartva azokat továbbjuttatják a méhlepénybe vagy a tejbe. Feltehetőleg azok a szérumban lévő anyai antitestek, amelyek később a tejbe kiválasztódnak, képesek az anyai szervezetben elfogni és megtartani a mikrobiális termékeket. Bizonyíték van arra, hogy az anyai szervezetben az E. coli-specifikus ellenanyagok felelősek a baktériumtermékek elfogásáért és azoknak a tejbe, majd az utódokba történő átjuttatásáért [32].

Nyilvánvaló, hogy a mikrobiota-specifikus antitestek képesek baktériumfragmentumokhoz kötődni, így az anyai szervezetben nagyobb a mikrobiota-eredetú metabolitok retenciója, és ezáltal ezek hatékonyabban jutnak át a méhlepénybe és az anyatejbe, tehát fel tudják készíteni az utódokat a megszületésük utáni immunológiai kihívásokra. Egy egérmodellben megfigyelték, hogy az anyai mikrobiota kulcsfontosságú szerepet játszik a magzati lymphoid szervek (csecsemőmirigy, csontvelő) és az immunsejtek (CD4+ ${ }^{+}$-sejtek, regulátor T-sejtek) fejlödésében. A mikrobiom kóros eltérései (például praeeclampsiában) a magzati immunválasz zavarait (humorális és celluláris) okozhatják [33]. A magzat az intrauterin 
rubeolavírus-fertőzésre - mely a mikrobiomját módosítja - adott válaszként már a 11. gestatiós héten IgM-ellenanyag termelésére képes, és a 17 . héten, igaz csak intrauterin fertőzések esetén, szérumában már kimutatható az endogén IgG-ellenanyag is [34].

A T-sejtek úgy tesznek különbséget az idegen és a gazdamolekulák között, hogy felismerik a különféle mikrobiális molekulákat, elsősorban a peptideket, a lipideket és a poliszacharid antigéneket. A terhesség második trimeszterétől kezdve MAIT-sejteket is azonosítottak a magzati bélben [10]. Ezek a sejtek képesek a mikrobiális metabolitok felismerésére és következésképpen gyulladásos citokinek termelésére, ami alátámasztja a méhen belüli immunaktivitás hipotézisét [10]. A sok baktériumban és az élesztőben található riboflavin prekurzorok szelektíven aktiválják többek között a MAIT-sejteket is, amelyek a humán újszülöttkori T-sejtek bőséges populációját alkotják. Ugyanakkor, miután sok vitamin bioszintetikus reakcióútja a baktériumokra és az élesztőkre nézve egyedi, a MAIT ezeket a vitaminmetabolitokat használja a mikrobiális fertőzés azonosítására.

Nemcsak a postnatalis kolonizáció játszik fontos szerepet az újszülött immunfenotípusának kialakításában, hanem a várandós mikrobiotájából származó molekuláris jelek - amelyek a méhben a méhlepényen és postnatalisan az anyatejen keresztül juthatnak el az utódokba - is szignifikánsan hozzájárulnak az újszülött immunrendszerének mikrobiális alakításához és beállításához [32].

A humán bélmikrobiota fontos szerepet játszik a gazdaszervezet homeostasisának fenntartásában, például a vitaminok előállításában és az oligo-, poliszacharidok lebontásában. Következésképpen a gazdaszervezetnek olyan környezetről kell gondoskodnia, amely szimpatikus ennek a kommenzális közösségnek, ugyanakkor véd is a patogén fajokkal szemben. Ehhez a gazdaszervezetnek fejlett immunrendszert kell kialakítania a káros és a jótékony hatású baktériumok megkülönböztetésére.

Számos tanulmány jelent meg, amely betekintést nyújt a magzati mikrobiota fent említett három lehetséges eredetébe. Az anyai és a magzati mikrobiomok közötti lehetséges összefüggéseket vázolja fel a 2. ábra. Fontos figyelembe venni azonban, hogy valószínúleg nem egyetlen forrásról van szó, hanem az eredet az egyes terhességekben változhat, továbbá hogy a magzati mikrobiota betelepedési folyamata dinamikus, és függhet a terhességi kortól is. A terhesség időtartama fontos lehet az anyai mikrobiomtranszferben, amelyet a koraszülött újszülöttek bélrendszerének vizsgálatai támasztanak alá, akiknél alacsonyabb a baktériumok variabilitása, mint a terminusban született újszülötteknél [27].

Az Ureaplasma spp.-t korábban már kimutatták a 20. héten elvégzett amniocentesismintákban, a Fusobacterium spp.-t a 21. héten és az Ureaplasma parvumot, a Citrobacter koserit és a viridans csoport Streptococcusokat a 22. héten. A közzétett adatok azonban arra utalnak, hogy 18-20 hetes terhességnél a legtöbb magzatvízmintában a bakteriális $16 \mathrm{~S}$ rDNS szintje nagyon alacsony vagy nem kimutatható. Ezért, bár úgy tűnik, hogy a kórokozó fajok a terhesség korai szakaszában bejuthatnak a méh üregébe, ez normális terhességben ritkán fordulhat eló, és továbbra sem tisztázott, hogy a kommenzális baktériumok betelepedése a magzatba mikor is jön létre. A gestatiós kor jelentős hatással van a meconium mikrobiális közösségének szerkezetére, így a proteobaktériumok és a Firmicutes prevalenciája negatív korrelációban van a terhességi korral. Pontosabban, a 33. héten született csecsemőkben szignifikánsan nagyobb arányban mutatták ki a $16 S$ rDNS szekvenciáját, ami az Enterococcus, az Enterobacter, a Lactobacillus, a Photorhabdus és a Tannerella spp. jelenlétét jelzi. Az újszülöttkori bélmikrobiota a leginkább az első trimeszterbeli anyai bélmikrobiotához hasonlít [6].

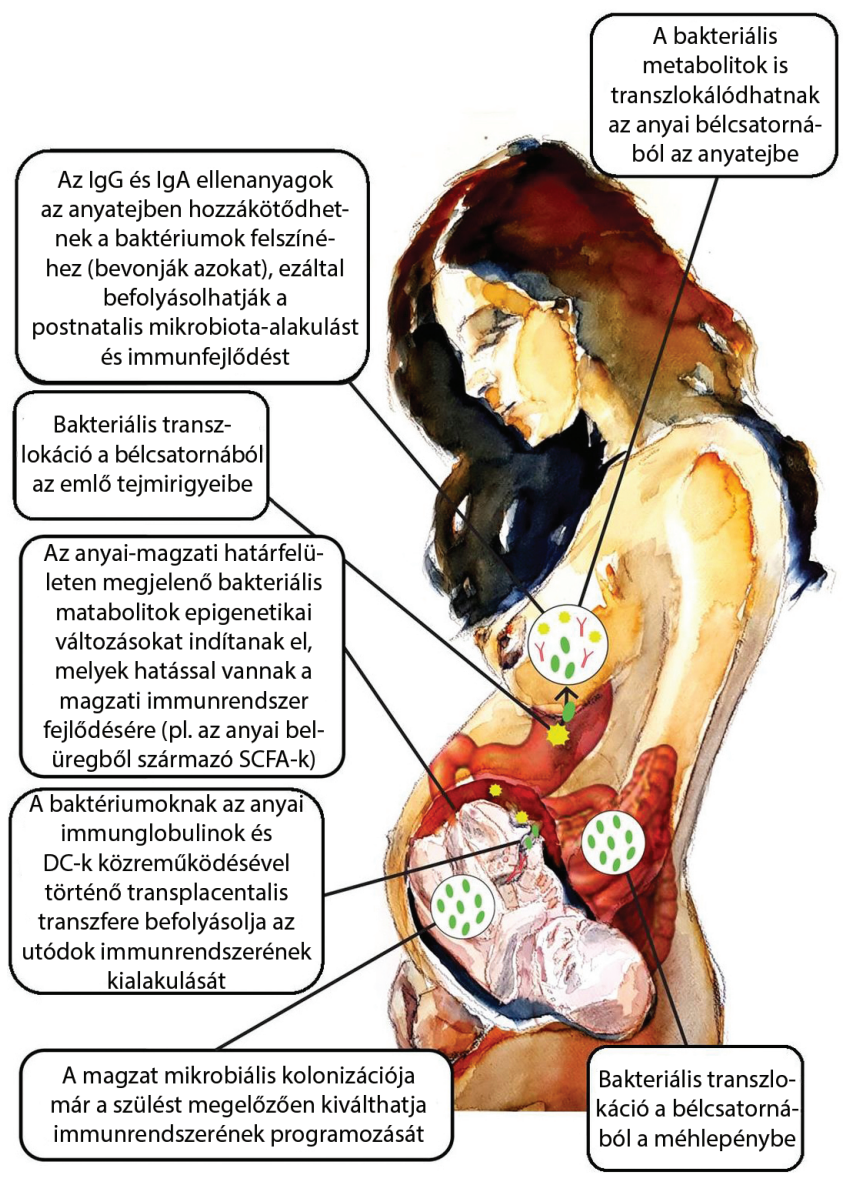

2. ábra

Az anyai mikrobiota és az utódok immunrendszerének múködé se közötti „áthallás” lehetséges mechanizmusai. Az anyai bél mikrobiota terhesség alatt transzlokálódik az anya-magzat határfelületére. A kommenzális mikrobák az anya bélcsatornájából a terhesség alatt transzlokálódnak a méhlepénybe, a magzati bélbe (anyai bélcsatorna-méhlepény tengely) és az emlő tejmirigyeibe. Ezek a mikrobák különböző mechanizmusok révén be folyásolják a magzati immunrendszer kialakulását, beleértve az epigenetikus változásokat, a rövid láncú zsírsavak (SCFA-k) felszabadulását és a citokinkörnyezet megváltoztatását. A baktériumok vagy a bakteriális metabolitok átjutnak az emlőmirigyekbe (anyai bélcsatorna-anyatej tengely), ami befolyásolja a csecsemő bélkolonizációját, és a szülés után is folytatódik immunrendszerének fejlődése (zöld szín: baktériumok és metabolitjaik; sárga szín: dendritikus sejtek [DC-k]; piros szín: immunglobulinok)

IgA = immunglobulin-A; IgG = immunglobulin- $\mathrm{G}$ 
A magzati mikrobiota eredetének meghatározásával lehetőség adódik a praenatalis és postnatalis egészségügyi intervenciókra a dysbiosis megelőzése és a nem fertőző betegségek előfordulásának és hatásának minimalizálása érdekében [6].

\section{Lehetséges kezelési intervenciók}

\section{Pre-, pro-és szimbiotikum}

Régóta próbálkozunk azzal, hogy a változásokat számunkra kedvezően tudjuk alakítani, így akár egészség és betegség viszonyát is megváltoztatni [35]. Ugyanakkor a mikrobiom és a szervezetünk kétirányú kapcsolatában nemcsak mi befolyásolhatjuk bélflóránkat, hanem az is több szinten képes szervezetünk müködését szabályozni. A mikrobák önmagukban is farmakológiai tényezők, amelyek képesek új gyógyszert létrehozni vagy a beadottat megváltoztatni, vagy önmaguk is hatnak gyógyszerként. Ez utóbbit nevezzük probiotikumnak, amellyel a bélflóránkat befolyásoljuk, akárcsak az antibiotikumokkal, de ezek élő mikroorganizmusok, amelyek megfelelő mennyiségben adva a gazdaszervezet számára egészségügyi haszonnal járnak [36].

A probiotikumok szaporodásához szükséges prebiotikumokkal is befolyásolható a bélflóra: ezek olyan szubsztrátok, amelyeket a célszervezet szelektíven fel tud használni, és az egészségre jótékony hatást gyakorolnak. A prebiotikumok nem emészthető étrend-kiegészítők, amelyek elősegítik a hasznos mikroorganizmusok növekedését a bélben. A pre- és a probiotikum kombinációja a szimbiotikum, míg a posztbiotikumok metabolitok és / vagy sejtfalkomponensek, amelyeket élő baktériumok, a probiotikumok termelnek, vagy lízis kapcsán szabadulnak fel, és szintén szabályozzák a mikrobiomunkat [37].

$\mathrm{Az}$ igazolt, probiotikumoknak tulajdonított hatások ugyanakkor életképtelen összetevőikből is származhatnak, ez lehet a posztbiotikumok egyik lehetséges hatásmechanizmusa. A probiotikus paradoxon tehát azt jelenti, hogy a probiotikumokélő, jótékony hatású mikroorganizmusok, de élettelen változatuk is hasznos biológiai választ hozhat létre a gazdasejtben. A probiotikumok hatása így kettős lehet: az élő probiotikus sejtek befolyásolják mind a gyomor-bél rendszeri mikroflórát, mind az immunválaszt, míg a halott sejtek összetevői gyulladáscsökkentő hatást fejtenek ki a gyomor-bél traktusban. Ugyanakkor az élettelen probiotikumok, így a posztbiotikumok biológiai válaszmódosítókként való alkalmazása számos vonzó előnynyel rendelkezik; az ilyen termékek nagyon biztonságosak és hosszú élettartamúak lehetnének [38].

A bélflóra befolyásolható még antibiotikumokkal, amelyek nemcsak terápiás adagban érvényesítik hatásukat, hanem már kis dózisban is. A modern élelmiszerekkel naponta bevitt adagban is elsősorban a zsírsavak szintjének befolyásolásával okoznak például túlsúlyt [39]. Az antibiotikumok mellett ugyanakkor újabban számos, széles körben használt más gyógyszercsoportról (így savcsökkentőkről, nemszteroid gyulladásgátlókról, antipszichotikumokról) is kiderült, hogy minden negyedik vegyületük a vizsgált 40 bélflóratagból legalább 1-nek csökkentette a növekedését in vitro [40].

Már régóta ismert, hogy a probiotikumok felhasználhatók a bél homeostasisának fenntartására és számos gastrointestinalis rendellenesség kezelésére, de a pontos patomechanizmus máig nem ismert. A közelmúltban egyre több bizonyíték támasztja alá azt az elképzelést, hogy bizonyos probiotikus komponensek - mint például a bakteriocinek, a lipoteicholsavak, a felszíni fehérje és a szekretált fehérje - hasonlóan védik a bél barrierfunkcióját, mint az élő probiotikumok. Ezeket a bioaktív komponenseket a legújabb publikációkban „posztbiotikumoknak" nevezték el. Vannak olyan körülmények, amikor pont hogy az élettelen biológiai ágens lehet az előnyösebb, szemben az élő, így akár fertőzőképesebb fajtával szemben. Az élő szervezetek beadása veszélyes lehet, különösen bizonyos populációkban. Így leírásra került már, hogy immunkompromittált populációkban, például koraszülöttek esetében, vagy mútét után adva pár esetben egyes probiotikumok sepsist okozhatnak. Ugyanakkor arról is beszámoltak, hogy bizonyos probiotikumok adása csökkenti a sepsis kockázatát a koraszülöttek esetében. Az eddig rendelkezésre álló kevés adat azt mutatja, hogy ezeknek az élő ágenseknek a hővel, sugárzással stb. inaktivált összetevői ugyanolyan hatékonyak és lényegesen biztonságosabbak lehetnek, mint a már ismert élő formáik [41]. Nem áll rendelkezésre elegendő bizonyíték arra, hogy a probiotikumok vagy prebiotikumok használata koraszülötteknél egyértelmúen biztonságos lenne, így alkalmazásuk pont az ebben a dysbiosisban leginkább érintett populációban ma még eléggé kérdéses.

Ezek alapján tehát szimbiotikus kapcsolat áll fenn a bélsejtek és az emésztőrendszeren belüli bélbaktériumok között. Ezen kölcsönhatás megváltoztatása vagy hiánya szerepet játszhat az emberi betegségek kialakulásában. A probiotikus organizmusok alkalmazása bizonyos orvosi állapotok javulását eredményezte, mint például gyulladásos és fertőző gyomor-bél rendszeri betegségek [42].

Tekintettel arra, hogy a várandós mikrobájával való in utero találkozás befolyásolja a magzati bél mikrobiális közösségének összetételét - amely viszont hosszú távú hatást gyakorol az immunrendszerre és annak kockázatára, hogy az élet későbbi szakaszában esetleg számos betegség kialakuljon (gyomor-bél rendszeri betegségek, allergiák, autoimmun betegségek és anyagcsere-betegségek) -, a praenatalis anyai oralis probiotikumkezelés olcsó, biztonságos és hatékony beavatkozási pontot jelenthet a betegségek megelőzésében. Az utóbbi években számos randomizált klinikai vizsgálatot végeztek, amelyek kimutatták, hogy a praenatalis probiotikumkezelés csökkentheti az allergia és az atopiás betegségek kockázatát [6].

$\mathrm{Az}$ anyai praenatalis prebiotikumkezelés eseteiben megfigyelték, hogy befolyásolja a csecsemők bélmikrobi- 
otáját. Egy egérmodellben Fujiwara és mtsai kimutatták, hogy az anyai étrend praenatalis fruktooligoszacharid prebiotikummal történő kiegészítése megváltoztatta az utódok bélmikrobiomját, és védelmet nyújtott a bőrgyulladásokkal szemben is [43].

Ha valóban létrejön a várandós mikrobáinak a magzatba történő átterjedése, akkor a terhesség alatti mikrobiom olyan módosítások célpontjaként szolgálhat, amelyek optimalizálják azt a folyamatot, hogy támogassa a hasznos mikrobák átvitelét, és visszaszorítsa a káros vagy patogén baktériumok transzferét a magzatba. Ez hatékonyan nyithatja meg az újszülött csecsemók egészségét célzó, mikrobiomot befolyásoló, személyre szabott kezelések lehetőségét, melyben új értelmezést kapna a 'gyógyítsd az anyát, gyógyítsd a babát' elképzelés.

Az anyának az újszülöttkori bélmikrobiotára kifejtett hatásai a laktációval folytatódnak.

\section{Mikrobiom és a születés}

Életünk döntő és sok mindent meghatározó pillanata a születés, de szervezetünk már az anyaméhen belül elkezdi a felkészülést a méhen kívüli életre. Az újszülött növekedését és fertőzésekre való fogékonyságát éppúgy meghatározza az anya bélflórája, mint az utód későbbi élete folyamán való fogékonyságát az esetleges fertőzésekre vagy autoimmun betegségekre [44]. Egészségünk a körülöttünk és bennünk élő többi élőlénytől is függ, mert az emberi szervezet nem önállóan, hanem számos organizmus környezetében és azokat magában hordozva is múködik [45]. Az orvoslás eszköztárának bővülésével manapság az élethosszon túlmenően életminőségünket nem elsősorban genetikai adottságaink, hanem a környezeti tényezók befolyásolják [46]. Ezek egyik legfontosabb része a környezet genetikai állományunkra gyakorolt hatásainak összessége, így az epigenetika is, amely által ismertté vált, hogy káros környezeti tényezők akár kedvezőtlen változásokat is okozhatnak genomunkban. A környezettel való kapcsolatunk egyik legnagyobb határfelülete a bélflóránk, továbbá korunkban számos népbetegségnek tartott kórkép a gyomor-bél rendszer megbetegedése, ezért váltak a bélbaktériumok újabban a kutatás középpontjává.

A bélflóra egyik döntő meghatározója a születés pillanata, így a császármetszéssel világra jött újszülöttek nagyobb eséllyel kapnak antibiotikumot, és több orvosi beavatkozáson esnek át életük kezdetén. Ugyanakkor az antibiotikum önmagában is csökkenti a bélflóra diverzitását, a jótékony hatású Bifidobacteriumok arányát. Ezzel együtt nagyobb valószínúséggel kapnak tápszert is ezek az újszülöttek, ami elnyújtja a hüvelyen át születettekéhez képest a dysbioticus bélflóra fennállását [47]. Ismert a császármetszés vagy a koraszülés rövid távú dysbiosist okozó hatása, de ugyanígy az is, hogy ezek az állapotok és a korai antibiotikumhasználat is rizikófaktora a későbbi életkorban számos allergiás, autoimmun, metabolikus és cardiovascularis betegségnek. Bár számos próbálkozás szolgálja azt a célt, hogy egy császármetszéssel, akár koraszülöttként világra jött gyermek bélflóráját a normál, időre született és anyatejjel táplált gyermekéhez hasonlóvá tegye (például a terminusban született újszülött bélcsatornájába anyai bélbaktériumok telepítése a legtermészetesebb és legköltséghatékonyabb módszernek tünik), de egyértelmü hatás még nem ismert $[48,49]$.

Anyagi támogatás: A kézirat megírása és a kapcsolódó munka anyagi támogatásban nem részesült.

Szerzői munkamegosztás: Valamennyi szerző (F. V., D. J. és Cs. Á.) aktívan részt vett a kézirat készítésében, és a cikk végleges változatát elolvasta és jóvá is hagyta.

Érdekeltségek: Egyik szerzőnek sincs a közlést etikailag gátló érdekeltsége és financiális elkötelezettsége.

\section{Köszönetnyilvánítás}

A kézirat elkészítéséhez nyújtott technikai segítségekért a szerzők köszönetüket fejezik ki dr. Kiss Attila András föorvosnak és Gyergyák Edina, valamint Zachár Krisztina könyvtárosoknak.

\section{Irodalom}

[1] Maranduba CM, De Castro SB, De Souza GT, et al. Intestinal microbiota as modulators of the immune system and neuroimmune system: impact on the host health and homeostasis. J Immunol Res. 2015; 2015: 931574.

[2] Thorburn AN, Macia L, Mackay CR. Diet, metabolites, and "western-lifestyle" inflammatory diseases. Immunity 2014; 40: 833-842.

[3] Smith K, McCoy KD, Macpherson AJ. Use of axenic animals in studying the adaptation of mammals to their commensal intestinal microbiota. Semin Immunol. 2007; 19: 59-69.

[4] Nuriel-Ohayon M, Neuman H, Koren O. Microbial changes during pregnancy, birth, and infancy. Front Microbiol. 2016; 7 : 1031 .

[5] Mor G, Aldo P, Alvero AB. The unique immunological and microbial aspects of pregnancy. Nat Rev Immunol. 2017; 17: 469482 .

[6] Stinson LF, Payne MS, Keelan JA. Planting the seed: origins, composition, and postnatal health significance of the fetal gastrointestinal microbiota. Crit Rev Microbiol. 2017; 43: 352-369.

[7] Romano-Keeler J, Weitkamp JH. Maternal influences on fetal microbial colonization and immune development. Pediatr Res. 2015; 77: 189-195.

[8] Moles L, Gòmez M, Heilig H, et al. Bacterial diversity in meconium of preterm neonates and evolution of their fecal microbiota during the first month of life. PLoS ONE 2013; 8: e66986.

[9] Bäckhed F, Roswall J, Peng Y, et al. Dynamics and stabilization of the human gut microbiome during the first year of life. Cell Host Microbe 2015; 17: 690-703. [Erratum: Cell Host Microbe $2015 ; 17: 852$.]

[10] Brugman S, Perdijk O, van Neerven R, et al. Mucosal immune development in early life: setting the stage. Arch Immunol Ther Exp (Warsz). 2015; 63: 251-268.

[11] Smolen KK, Ruck CE, Fortuno ES 3rd, et al. Pattern recognition receptor-mediated cytokine response in infants across 4 continents. J Allergy Clin Immunol. 2014; 133: 818-826.e4.

[12] D'Argenio V. The prenatal microbiome: a new player for human health. High Throughput 2018; 7: 38. 
[13] Gosalbes MJ, Llop S, Vallès Y, et al. Meconium microbiota types dominated by lactic acid or enteric bacteria are differentially associated with maternal eczema and respiratory problems in infants. Clin Exp Allergy 2013; 43: 198-211

[14] Mshvildadze M, Neu J, Shuster J, et al. Intestinal microbial ecology in premature infants assessed with non-culture-based techniques. J Pediatr. 2010; 156: 20-25.

[15] Chu DM, Ma J, Prince AL, et al. Maturation of the infant microbiome community structure and function across multiple body sites and in relation to mode of delivery. Nat Med. 2017; 23: 314-326.

[16] Jiménez E, Fernández L, Marín ML, et al. Isolation of commensal bacteria from umbilical cord blood of healthy neonates born by cesarean section. Curr Microbiol. 2005; 51: 270-274.

[17] Dominguez-Bello MG, Costello EK, Contreras M, et al. Delivery mode shapes the acquisition and structure of the initial microbiota across multiple body habitats in newborns. Proc Natl Acad Sci USA 2010; 107: 11971-11975.

[18] Del Chierico F, Vernocchi P, Petrucca A, et al. Phylogenetic and metabolic tracking of gut microbiota during perinatal development. PLoS ONE 2015; 10: e0137347.

[19] Aagaard K, Ma J, Antony KM, et al. The placenta harbors a unique microbiome. Sci Transl Med. 2014; 6: $237 \mathrm{ra} 65$.

[20] Stokholm J, Schjørring S, Eskildsen CE, et al. Antibiotic use during pregnancy alters the commensal vaginal microbiota. Clin $\mathrm{Mi}-$ crobiol Infect. 2014; 20: 629-635.

[21] Chen X, Li P, Liu M, et al. Gut dysbiosis induces the development of pre-eclampsia through bacterial translocation. Gut 2020; 69: 513-522.

[22] Zijlmans MA, Korpela K, Riksen-Walraven JM, et al. Maternal prenatal stress is associated with the infant intestinal microbiota. Psychoneuroendocrinology 2015; 53: 233-245.

[23] Brzozowski B, Mazur-Bialy A, Pajdo R. Mechanisms by which stress affects the experimental and clinical inflammatory bowel disease (IBD): role of brain-gut axis. Curr Neuropharmacol 2016; 14: 892-900.

[24] Kelsall B. Recent progress in understanding the phenotype and function of intestinal dendritic cells and macrophages. Mucosal Immunol. 2008; 1: 460-469.

[25] Perez PF, Doré J, Leclerc M, et al. Bacterial imprinting of the neonatal immune system: lessons from maternal cells? Pediatrics 2007; 119: e724-7e32.

[26] Gomez-Arango LF, Barrett HL, McIntyre HD, et al. Contributions of the maternal oral and gut microbiome to placental mi crobial colonization in overweight and obese pregnant women. Sci Rep. 2017; 7: 2860

[27] Walker RW, Clemente JC, Peter I, et al. The prenatal gut microbiome: are we colonized with bacteria in utero? Pediatr Obes. 2017; 12(Suppl 1): 3-17.

[28] Kacerovsky M, Pliskova L, Bolehovska R, et al. The impact of the microbial load of genital mycoplasmas and gestational age on the intensity of intraamniotic inflammation. Am J Obstet Gynecol. 2012; 206: 342.el-342.e8.

[29] Kozyrskyj AL, Kalu R, Koleva PT, et al. Fetal programming of overweight through the microbiome: boys are disproportionately affected. J Dev Orig Health Dis. 2016; 7: 25-34.

[30] Soderborg TK, Borengasser SJ, Barbour LA, et al. Microbial transmission from mothers with obesity or diabetes to infants: an innovative opportunity to interrupt a vicious cycle. Diabetologia 2016; 59: 895-906.

[31] Gomez de Agüero M, Ganal-Vonarburg SC, Fuhrer T, et al. The maternal microbiota drives early postnatal innate immune development. Science 2016; 351: 1296-1302.

[32] Ganal-Vonarburg SC, Fuhrer T, Gomez de Agüero M. Maternal microbiota and antibodies as advocates of neonatal health. Gut Microbes 2017; 8: 479-485.
[33] Hu M, Eviston D, Hsu P, et al. Decreased maternal serum acetate and impaired fetal thymic and regulatory $\mathrm{T}$ cell development in preeclampsia. Nat Commun. 2019; 10: 3031.

[34] Fülöp V. Immunological characteristics of the fetus and the newborn. In Fülöp V. (ed.) Current issues in immunology in human reproduction. [A magzat és az újszülött immunológiai jellemzói. In: Fülöp V. (szerk.) Az immunológia időszerú kérdései a humánreprodukcióban.] Semmelweis Kiadó, Budapest, 2008; pp. 93-100. [Hungarian]

[35] Davis EC, Dinsmoor AM, Wang M, et al. Microbiome composition in pediatric populations from birth to adolescence: impact of diet and prebiotic and probiotic interventions. Dig Dis Sci. 2020; 65: 706-722.

[36] Gibson GR, Hutkins R, Sanders ME. Expert consensus document: The International Scientific Association for Probiotics and Prebiotics (ISAPP) consensus statement on the definition and scope of prebiotics. Nat Rev Gastroenterol Hepatol. 2017; 14: 491-502.

[37] Aguilar-Toalá, JE, García-Varela R, Garcia HS. Postbiotics: an evolving term within the functional foods field. Trends Food Sci Tech. 2018; 75: 105-114.

[38] Adams CA. The probiotic paradox: live and dead cells are biological response modifiers. Nutr Res Rev. 2010; 23: 37-46.

[39] Cho I, Yamanishi S, Cox L, et al. Antibiotics in early life alter the murine colonic microbiome and adiposity. Nature 2012; 488: 621-626.

[40] Maier L, Pruteanu M, Kuhn M, et al. Extensive impact of nonantibiotic drugs on human gut bacteria. Nature 2018; 555 : 623628.

[41] Kataria J, Li N, Wynn JL, et al. Probiotic microbes: do they need to be alive to be beneficial? Nutr Rev. 2009; 67: 546-550.

[42] Agostoni C, Buonocore G, Carnielli VP. Enteral nutrient supply for preterm infants: commentary from the European Society of Paediatric Gastroenterology, Hepatology and Nutrition Committee on Nutrition. J Pediatr Gastroenterol Nutr. 2010; 50: 85-91.

[43] Fujiwara R, Takemura N, Watanabe J, et al. Maternal consumption of fructo-oligosaccharide diminishes the severity of skin inflammation in offspring of NC/Nga mice. Br J Nutr. 2010; 103: $530-538$.

[44] Mesa MD, Loureiro B, Iglesia I, et al. The evolving microbiome from pregnancy to early infancy: a comprehensive review. Nutrients $2020 ; 12: 133$.

[45] Toor D, Wsson MK, Kumar P, et al. Dysbiosis disrupts gut immune homeostasis and promotes gastric diseases. Int J Mol Sci. 2019; 20: 2432.

[46] Gluckman PD, Hanson MA, Mitchell MD. Developmental origins of health and disease: reducing the burden of chronic disease in the next generation. Genome Med. 2010; 2: 14 .

[47] Sandall J, Tribe RM, Avery L, et al. Short-term and long-term effects of caesarean section on the health of women and children. Lancet 2018; 392: 1349-1357.

[48] Korpela K, de Vos WM. Early life colonization of the human gut: microbes matter everywhere. Curr Opin Microbiol. 2018; 44: $70-78$.

[49] Korpela K, Helve O, Kolho KL, et al. Maternal fecal microbiota transplantation in cesarean-born infants rapidly restores normal gut microbial development: a proof-of-concept study. Cell 2020; 183: 324-334.e5.

(Fülöp Vilmos dr.,

Budapest, Podmaniczky u. 111., 1062 e-mail: fvilmos@gmail.com)

A cikk a Creative Commons Attribution 4.0 International License (https://creativecommons.org/licenses/by/4.0/) feltételei szerint publikált Open Access közlemény. (SID_1) 